Article

\title{
Fast-Response Liquid Crystal Phase Modulators with an Excellent Photostability
}

\author{
Qian Yang ${ }^{\circledR}$, Junyu Zou, Yannanqi Li and Shin-Tson $\mathbf{W u} * \mathbb{C}$ \\ College of Optics and Photonics, University of Central Florida, Orlando, FL 32816, USA; \\ qianyang@knights.ucf.edu (Q.Y.); zoujunyuwinnie@Knights.ucf.edu (J.Z.); yannanqili@Knights.ucf.edu (Y.L.) \\ * Correspondence: swu@creol.ucf.edu; Tel.: +1-407-823-4763
}

Received: 20 August 2020; Accepted: 28 August 2020; Published: 29 August 2020

\begin{abstract}
We report a new mixture, which is modified from Merck TL-216, for liquid-crystal-on-silicon spatial light modulators (SLMs). To achieve $2 \pi$ phase change at $\lambda=633 \mathrm{~nm}$ with $5 \mathrm{~V}$ operation voltage, the measured response time is about $3 \mathrm{~ms}$ at $50^{\circ} \mathrm{C}$. Meanwhile, our mixture exhibits no sign of photodegradation and even the total dosage has exceeded $400 \mathrm{MJ} / \mathrm{cm}^{2}$ at a blue laser wavelength $\lambda=465 \mathrm{~nm}$. In comparison, E7 died at about $30 \mathrm{MJ} / \mathrm{cm}^{2}$. Widespread applications of this material for high brightness SLMs, near-eye displays, and head-up displays are foreseeable.
\end{abstract}

Keywords: liquid crystals; spatial light modulator; liquid-crystal-on-silicon; photostability

\section{Introduction}

Liquid crystals (LCs) have been widely used in display devices [1,2], such as augmented reality (AR) and virtual reality (VR) [3], tablets, computers, TVs, vehicle displays, and data projectors, to name a few. For amplitude modulation, the required phase retardation $(\delta=2 \pi d \Delta n / \lambda)$ is about $1 \pi$, depending on the LC mode employed [4], where $d$ is the cell gap, $\Delta n$ is the LC birefringence, and $\lambda$ is the wavelength. For display applications, the central wavelength is $\lambda=550 \mathrm{~nm}$ and the cell gap is controlled at $3 \mu \mathrm{m}$ in order to obtain fast response time and high manufacturing yield. Under such conditions, the required $\Delta n$ is approximately 0.1 . For such a low $\Delta n$ LC material, fluorinated cyclohexane-phenyl compounds [5-7] are commonly used. These compounds exhibit low viscosity, high resistivity, and excellent photostability.

On the other hand, phase-only liquid-crystal-on-silicon (LCOS) panels [8-10] have also found widespread application in adaptive optics for wavefront corrections [11], beam shaping for lithography [12], telecom as a wavelength selective switch [13], and multifocal displays [14-16] for overcoming the vergence-accommodation conflict issue in AR and head-up displays [17]. For such a spatial light modulator (SLM), the required phase change is $2 \pi$ and the response time should be less than $4 \mathrm{~ms}$ to support the desired $240 \mathrm{~Hz}$ frame rate. From the focal surface displays [18,19], both Oculus and Microsoft SLMs are operated at $60 \mathrm{~Hz}$, which is four times too slow to meet the desired $240 \mathrm{~Hz}$. Therefore, there is an urgent need to develop a phase-only LCoS SLM with response time $(\tau)$ less than $4 \mathrm{~ms}$, while keeping a $2 \pi$ phase change, low operation voltage ( $\leq 5 V_{r m s}$, the root-mean-square voltage) without the overdrive and undershoot driving circuitry, and excellent photostability, especially in the blue spectral region.

To achieve fast response time while keeping a low operating voltage, a straightforward method is to reduce the cell gap. LCoS is a reflective device, which means the incident light traverses the LC layer twice [20]. For example, to achieve $2 \pi$ phase change at $\lambda=633 \mathrm{~nm}$ using a $1.5 \mu \mathrm{m}$ cell gap, the required $\Delta n$ is 0.211 . Moreover, the actual operating temperature of $L C o S$ is $40-50{ }^{\circ} \mathrm{C}$ due to the thermal effects from the CMOS (complementary metal-oxide-semiconductor) backplane and high-power light source [21]. As the temperature increases, both viscoelastic constant and birefringence 
decrease but at different rates [22]. The former helps to achieve fast response time, but the latter demands a slightly thicker cell gap or a higher birefringence at the room temperature. In the meantime, photostability of the employed high $\Delta n$ LC materials and alignment layers is essential for extending the SLM lifetime [23,24]. LCoS projection displays are usually illuminated by a relatively high-power arc lamp, light emitting diodes, or lasers. Even if the ultraviolet and infrared parts of the arc lamp light source are filtered out, the remaining blue light may still degrade the device lifetime. These high-energy photons could decompose the LC compounds or deteriorate the polyimide alignment layer, which in turn changes the pretilt angle of the LC and consequently affects the electro-optic properties. Inorganic SiOx alignment layers [25] have been found to sustain long-term UV and blue light exposure without damage [26], but the photostability of high $\Delta n$ LC materials, especially in the blue spectral region, have not been investigated thoroughly.

In this paper, we report a new LC mixture optimized for the LCoS SLMs. Its modest birefringence and low viscoelastic constant jointly contribute to fast response time $\left(\sim 3.14 \mathrm{~ms} @ 50^{\circ} \mathrm{C}\right)$ and its stable chemical structure exhibits an excellent photostability at $\lambda=465 \mathrm{~nm}$ for a dosage over $400 \mathrm{MJ} / \mathrm{cm}^{2}$.

\section{LC Mixture Formulation}

We have evaluated several commercial high birefringence LC mixtures, including E7 and Merck TL-213 and TL-216. Among them, TL-216 exhibits an excellent photostability at $\lambda=465 \mathrm{~nm}$. However, as will be shown later, its response time falls short of our targeted $4 \mathrm{~ms}$ for $240 \mathrm{~Hz}$ operation. The response time of an LC material is proportional to the cell gap squared $\left(\mathrm{d}^{2}\right)$. To keep the same $2 \pi$ phase change for an LCoS, the most effective method is to reduce the cell gap by increasing LC birefringence. Therefore, our strategy is to dope Merck TL-216 with a high $\Delta n$, large dielectric anisotropy $(\Delta \varepsilon)$ and low-viscosity trifluoro-terphenyl compound (abbreviated as PPP-3FFF), whose molecular structure is shown in Figure 1.

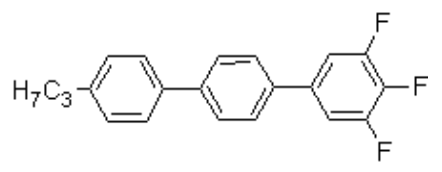

Figure 1. Chemical structure of trifluoro-terphenyl compound.

The melting temperature of PPP-3FFF is $118.7^{\circ} \mathrm{C}$ and heat fusion anthalpy is $4039 \mathrm{cal} / \mathrm{mol}$ [27]. Although it does not have a nematic phase, in experiment we doped $15 \%$ and $20 \%$ PPP-3FFF into TL-216 and the mixtures remain liquid at $22{ }^{\circ} \mathrm{C}$. The $20 \%$ mixture exhibits a slightly higher $\Delta n$ and larger $\Delta \varepsilon$ than the $15 \%$ one. We named this mixture ( $80 \mathrm{wt} . \% \mathrm{TL}-216+20 \mathrm{wt} . \%$ PPP-3FFF) as UCF-216 and use it for all the electro-optic and photostability studies reported here.

\section{Material Characterizations}

First, we characterize and compare the physical properties of TL-216 and UCF-216. Their phase transition temperatures and physical properties $\left(\right.$ at $\mathrm{T}=22^{\circ} \mathrm{C}$ ) are summarized in Table 1 . We measured the melting temperature $\left(T_{m}\right)$ and clearing temperature $\left(T_{c}\right)$ by differential scanning calorimetry (DSC, TA Instruments Q100). The wide nematic range $\left(-20^{\circ} \mathrm{C} \sim 80^{\circ} \mathrm{C}\right)$ satisfies the requirement for most LCoS applications. We also measured the dielectric constants with a multifrequency LCR meter, HP-4274. The viscoelastic constant $\gamma_{1} / K_{11}$ of each mixture was measured from the free relaxation response time of a test cell. The relatively low $\gamma_{1} / K_{11}$ effectively helps to reduce the response time. 
Table 1. Measured physical properties of TL-216 and UCF-216 at $T=22{ }^{\circ} \mathrm{C}$.

\begin{tabular}{ccc}
\hline LC mixture & TL-216 & UCF-216 \\
\hline$T_{c}\left({ }^{\circ} \mathrm{C}\right)$ & 80.0 & 81.8 \\
$T_{m}\left({ }^{\circ} \mathrm{C}\right)$ & -20 & -20 \\
$\Delta n @ 633 \mathrm{~nm}$ & 0.205 & 0.215 \\
$\Delta \varepsilon @ 1 \mathrm{kHz}$ & 5.5 & 7.6 \\
$\varepsilon_{\perp} @ 1 \mathrm{kHz}$ & 4.2 & 4.2 \\
$K_{11}(\mathrm{pN})$ & 14.4 & 14.6 \\
$K_{33}(\mathrm{pN})$ & 19.6 & - \\
$\gamma_{1} / K_{11}\left(\mathrm{~ms} / \mu \mathrm{m}^{2}\right)$ & 19.0 & 14.5 \\
\hline
\end{tabular}

\subsection{Birefringence}

Birefringence determines the cell gap, which in turn affects the response time. To measure $\Delta n$, we filled each LC mixture into a homogeneous cell with cell gap $\mathrm{d} \approx 5 \mu \mathrm{m}$. The pretilt angle of the rubbed polyimide alignment layers is about $3^{\circ}$. We sandwiched each cell between crossed polarizers and activated it with a $1 \mathrm{kHz}$ square-wave AC voltage. The sample temperature was controlled by a Linkam heating stage through a temperature programmer TMS94. The birefringence was calculated from the measured phase retardation. Figure 2 depicts the temperature-dependent birefringence at $\lambda=633 \mathrm{~nm}$ (He-Ne laser), where dots represent the measured data and solid lines represent the fitting with following equation [28,29]:

$$
\Delta n=\Delta n_{0} S=\Delta n_{0}\left(1-T / T_{c}\right)^{\beta} .
$$

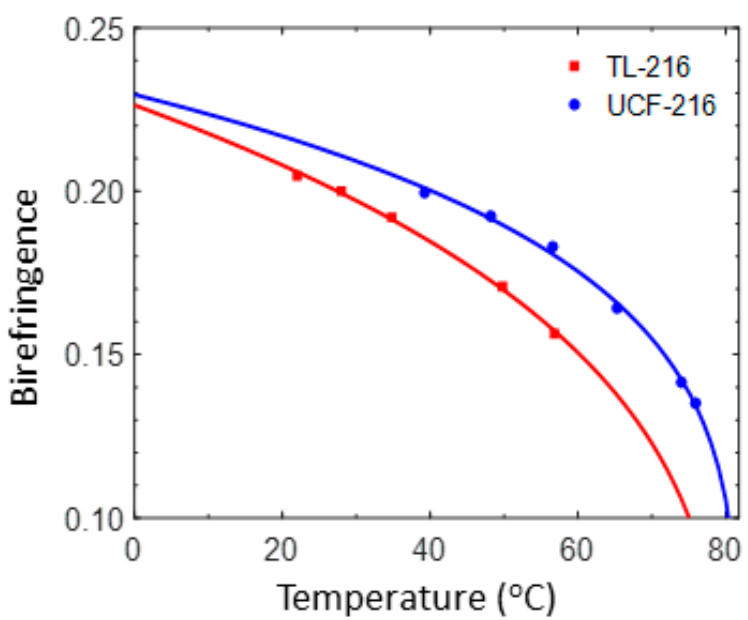

Figure 2. Temperature-dependent birefringence of TL-216 and UCF-216 at $\lambda=633 \mathrm{~nm}$ and $1 \mathrm{kHz}$. Dots are measured data and solid lines are fitting curves with Equation (1). The fitting parameters are listed in Table 2.

Table 2. Fitting parameters obtained through Equations (1) and (2).

\begin{tabular}{ccccc}
\hline LC Mixture & $\boldsymbol{\Delta} \boldsymbol{n}_{\mathbf{0}}$ & $\boldsymbol{\beta}$ & $\begin{array}{c}\boldsymbol{A} \\
\left(\mathbf{m s} / \boldsymbol{\mu \mathbf { m } ^ { 2 } )}\right.\end{array}$ & $\begin{array}{c}\boldsymbol{E}_{\boldsymbol{a}} \\
(\mathbf{m e V})\end{array}$ \\
\hline TL-216 & 0.350 & 0.294 & $1.23 \times 10^{-6}$ & 406.0 \\
UCF-216 & 0.309 & 0.203 & $2.12 \times 10^{-4}$ & 272.0 \\
\hline
\end{tabular}

In Equation (1), $\Delta \mathrm{n}_{0}$ stands for the extrapolated birefringence at $\mathrm{T}=0 \mathrm{~K}, S$ is the order parameter, $T_{\mathcal{c}}$ (unit: $\mathrm{K}$ ) is the clearing temperature of the $\mathrm{LC}$, and exponent $\beta$ is a material parameter. Both $\Delta \mathrm{n}_{0}$ 
and $\beta$ can be obtained by fitting the experimental data with Equation (1). Results are listed in Table 2 . For convenience, we use Celsius $\left({ }^{\circ} \mathrm{C}\right)$ instead of Kelvin temperature $(\mathrm{K})$ in Figures 2 and 3.

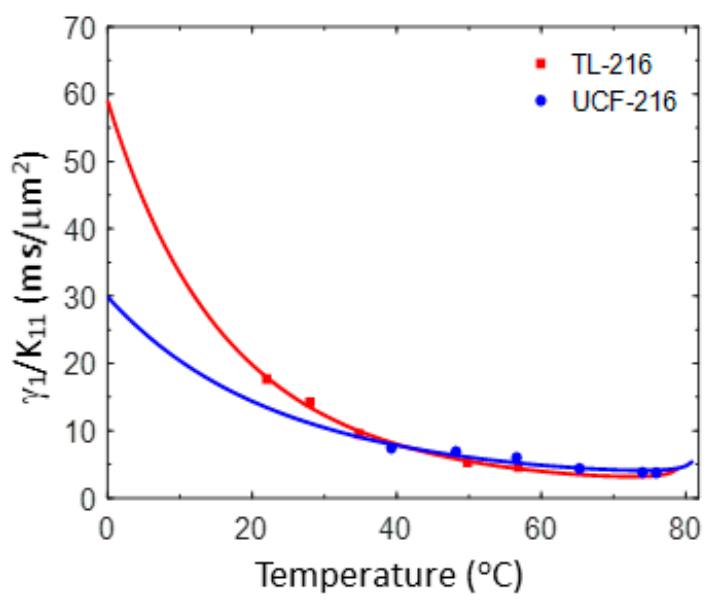

Figure 3. Temperature-dependent viscoelastic constant of TL-216 and UCF-216. Dots are measured data and solid lines are fitting curves using Equation (2). The fitting parameters are listed in Table 2.

\subsection{Viscoelastic Constant}

We also measured the transient decay time of these two LC materials and obtained the temperature-dependent viscoelastic constant $\gamma_{1} / K_{11}$, shown by the dots presented in Figure 3 . The solid lines represent fittings with following equation [22]:

$$
\frac{\gamma_{1}}{K_{11}}=A \frac{\exp \left(E_{a} / k_{B} T\right)}{\left(1-T / T_{c}\right)^{\beta}}
$$

In Equation (2), $A, E_{a}$, and $K_{B}$ stand for the proportionality constant, activation energy, and Boltzmann constant, respectively. The fitting parameters are also included in Table 2. From Figure 3 and Equation (2), we can see that $\gamma_{1} / K_{11}$ decreases dramatically as the temperature increases and then gradually saturates as the temperature approaches to the clearing point.

\subsection{Voltage Dependent Phase Change}

As mentioned above, for a working $\mathrm{LCoS}$ device, its operating temperature is about $40-50{ }^{\circ} \mathrm{C}$ due to the thermal effects of CMOS backplane and the high-power light source. Therefore, we focus our studies at two temperatures: $40^{\circ} \mathrm{C}$ and $50{ }^{\circ} \mathrm{C}$. The voltage-dependent phase $(V-\Phi)$ curves of these materials can be converted from the voltage-dependent transmittance $(\mathrm{V}-\mathrm{T})$ curve measured at $\lambda=633 \mathrm{~nm}$. Figure $4 \mathrm{a}, \mathrm{b}$ depicts the $V$ - $\Phi$ curve of TL-216 $(d=4.99 \mu \mathrm{m})$ at $40{ }^{\circ} \mathrm{C}$ and $50{ }^{\circ} \mathrm{C}$, respectively. Although the LCoS is a reflective device, our measurements were conducted in transmissive cells, because we did not have such a thin LC cell in our labs. Our measured results can be converted to the corresponding reflective cells easily. From Figure 4, the $V_{2 \pi}$ of TL-216 occurs at $4.7 V_{r m s}$ at $40^{\circ} \mathrm{C}$ and $4.9 \mathrm{~V}_{\mathrm{rms}}$ at $50^{\circ} \mathrm{C}$ (red lines). To explain the slightly increased $V_{2 \pi}$, we have to consider two factors as the temperature increases: (1) decreased birefringence and (2) decreased threshold voltage $\left(\mathrm{V}_{\text {th }}\right)$. The former is more apparent than the latter, leading to a slightly higher $V_{2 \pi}$ at $50^{\circ} \mathrm{C}$. It should be mentioned that our allowed $V_{2 \pi}$ is $5 V_{r m s}$, that means we can use a slightly thinner cell gap to achieve the desired $2 \pi$ phase change. The $V$ - $\Phi$ curve of a different cell gap can be extrapolated by simply using the phase retardation equation $\delta=2 \pi d \Delta \mathrm{n} / \lambda$. If we operate TL-216 at $50{ }^{\circ} \mathrm{C}$, we could use a slightly thinner cell gap ( $4.93 \mu \mathrm{m}$ transmissive cell or $2.47 \mu \mathrm{m}$ reflective LCoS) to obtain $V_{2 \pi}$ at $5 V_{\text {rms }}$, as the blue line shows. A thinner cell gap leads to a faster response time, which will be discussed quantitatively later. 

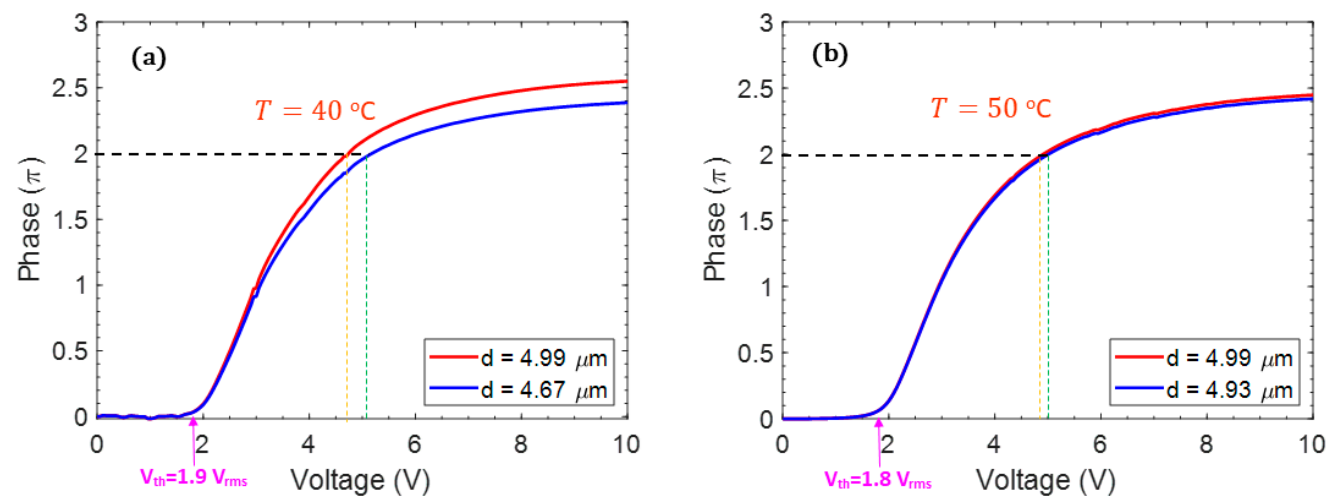

Figure 4. Measured (red line) voltage-dependent phase change of a transmissive TL-216 test cell at $\lambda=633 \mathrm{~nm}$ and $1 \mathrm{kHz}$. Cell gap is $d=4.99 \mu \mathrm{m}$, with $V_{2 \pi}=4.7 V_{r m s}$ at $T=40^{\circ} \mathrm{C}$ in (a) and with $V_{2 \pi}$ $=4.9 V_{r m s}$ at $T=50{ }^{\circ} \mathrm{C}$ in (b). If we operate TL-216 at $50{ }^{\circ} \mathrm{C}$, we could use a slightly thinner cell gap $\left(4.93 \mu \mathrm{m}\right.$ transmissive cell or $2.47 \mu \mathrm{m}$ reflective $\mathrm{LCoS}$, blue line in (b)) to increase $V_{2 \pi}$ to $5 V_{\text {rms }}$.

Similar measurements and extrapolations apply to UCF-216 using a $d=5.01 \mu \mathrm{m}$ transmissive cell at $\lambda=633 \mathrm{~nm}$. Figure $5 \mathrm{a}, \mathrm{b}$ shows the measured and extrapolated voltage-dependent phase change of UCF- 216 at $40{ }^{\circ} \mathrm{C}$ and $50{ }^{\circ} \mathrm{C}$. At $50{ }^{\circ} \mathrm{C}$, as the red line shows, $V_{2 \pi}$ occurs at $3 V_{r m s}$ because of its higher $\Delta n$ and lower threshold voltage $\left(1.2 V_{r m s}\right)$. Since our allowed $V_{2 \pi}$ is $5 V_{r m s}$, we can reduce the cell gap to $4.14 \mu \mathrm{m}$, as the blue line indicates in Figure $5 \mathrm{~b}$. For reflective mode operation, this corresponds to $d=2.07 \mu \mathrm{m}$.
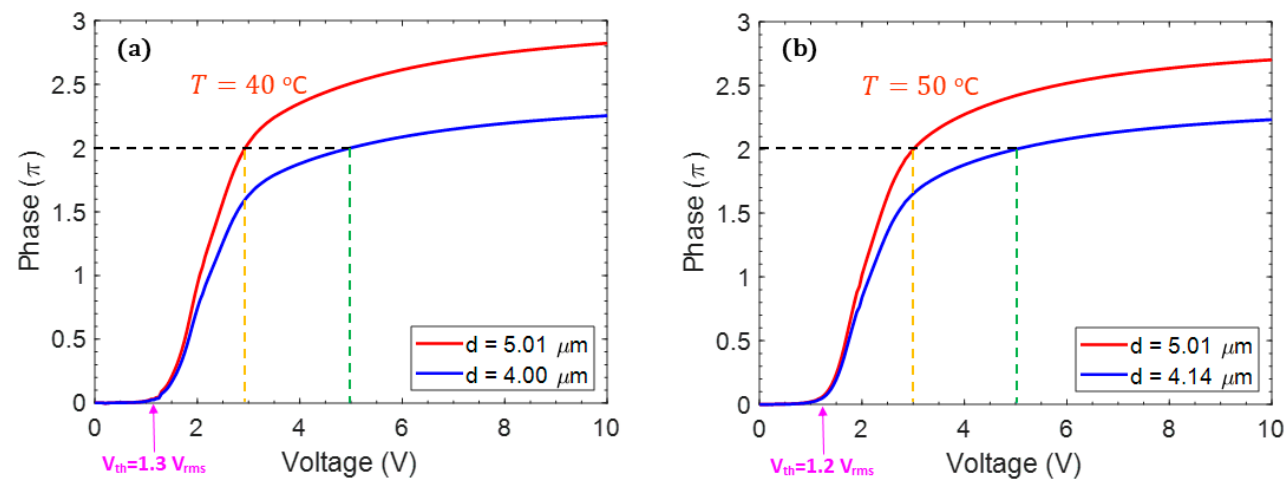

Figure 5. Measured (red line) voltage-dependent phase change of a transmissive UCF-216 test cell at $\lambda=633 \mathrm{~nm}$ and $1 \mathrm{kHz}$. Cell gap is $d=5.01 \mu \mathrm{m}$, with $V_{2 \pi}=2.9 V_{r m s}$ at $\mathrm{T}=40{ }^{\circ} \mathrm{C}$ in (a) and with $V_{2 \pi}=3 V_{r m s}$ at $\mathrm{T}=50{ }^{\circ} \mathrm{C}$ in (b). If we allow $V_{2 \pi}=5.0 V_{r m s}$, then we can reduce the cell gap to $4.14 \mu \mathrm{m}$ (blue line in (b)), which is equivalent to $2.07 \mu \mathrm{m}$ in a reflective LCoS panel.

\subsection{Response Time}

The switching time (rise time and decay time) between two gray levels $\left(V_{1}\right.$ and $\left.V_{2}\right)$ of an LC phase modulator are governed by the LC cell gap, viscoelastic constant, and operating voltages as [30]:

$$
\begin{gathered}
\tau_{o n}=\frac{\tau_{0}}{\left(V_{2} / V_{t h}\right)^{2}-1}, \\
\tau_{\text {off }}=\frac{\tau_{0}}{\left|\left(V_{1} / V_{t h}\right)^{2}-1\right|}, \\
\tau_{0}=\frac{\gamma_{1} d^{2}}{K_{11} \pi^{2}} .
\end{gathered}
$$

In Equations (3)-(5), $V_{t h}$ is the threshold voltage, $V_{2}$ is the high gray-level voltage, $V_{1}$ is the low gray-level voltage, and $\tau_{0}$ is the free relaxation time, i.e., $V_{1}=0$. From Equations (3) and (4), 
the response time near $V_{\text {th }}$ is sluggish. In Figure $5 \mathrm{~b}$, at $50{ }^{\circ} \mathrm{C}$, because $V_{2 \pi}$ of UCF-216 with cell gap $\mathrm{d}=5.01 \mu \mathrm{m}$ is not too far from the threshold voltage $\left(V_{t h}=1.2 V_{r m s}\right)$, according to Equation (3) the rise time will be slow. From our previous studies [31,32], the average gray-to-gray rise time and decay time is about the same as the sum of turn-on time $\left(V_{2}=8\right.$ th gray level; in our case $\left.5 \mathrm{~V}\right)$ and free relaxation time $\left(V_{1}=0\right)$.

We then measured the rise time and decay time of TL-216 and UCF-216 at two different temperatures and converted these data into reflective cells. Table 3 summarizes the measured response time of TL-216, using a $\mathrm{d}=4.99 \mu \mathrm{m}$ transmissive cell at $\lambda=633 \mathrm{~nm}$ and $\mathrm{T}=40^{\circ} \mathrm{C}$ and $50{ }^{\circ} \mathrm{C}$. From Table 3, TL-216 can achieve $12 \mathrm{~ms}$ at $\mathrm{T}=40^{\circ} \mathrm{C}$ with $V_{2 \pi}=4.7 V_{r m s}$, and $6.9 \mathrm{~ms}$ at $50{ }^{\circ} \mathrm{C}$ with $V_{2 \pi}=4.9 V_{r m s}$. If we operate TL-216 at $50{ }^{\circ} \mathrm{C}$ with a cell gap of $4.93 \mu \mathrm{m}$ transmissive cell to satisfy $V_{2 \pi}=5 V_{r m s}$, the total response time $\tau_{\text {on }}+\tau_{\text {off }}=6.7 \mathrm{~ms}$, which is about $1.6 \times$ slower than the desired $4 \mathrm{~ms}$.

Table 3. Measured response time of a transmissive TL-216 cell with $d=4.99 \mu \mathrm{m}$, and the extrapolated response time to the corresponding reflective cells at $40^{\circ} \mathrm{C}$ and $50{ }^{\circ} \mathrm{C} . \lambda=633 \mathrm{~nm}$.

\begin{tabular}{cccccccc}
\hline $\mathbf{T}\left({ }^{\circ} \mathbf{C}\right)$ & $\mathbf{d}(\boldsymbol{\mu m})$ & $\boldsymbol{V}_{\boldsymbol{t h}}(\mathbf{V})$ & $\mathbf{V}_{\mathbf{2 \pi}}(\mathbf{V})$ & $\boldsymbol{\tau}_{\mathbf{o n}}(\mathbf{m s})$ & $\boldsymbol{\tau}_{\mathbf{o f f}}(\mathbf{m s})$ & $\begin{array}{c}\boldsymbol{\tau}_{\text {total }}(\mathbf{m s}) \\
\text { Transmissive }\end{array}$ & $\begin{array}{c}\boldsymbol{\tau}_{\text {total }}(\mathbf{m s}) \\
\text { Reflective }\end{array}$ \\
\hline 40 & 4.99 & 1.9 & 4.7 & 17.7 & 30.4 & 48.2 & 12.0 \\
40 & 4.67 & 1.9 & 5.1 & 12.5 & 26.6 & 39.2 & 9.8 \\
50 & 4.99 & 1.8 & 4.9 & 9.7 & 18.1 & 27.7 & 6.9 \\
50 & 4.93 & 1.8 & 5.0 & 9.0 & 17.6 & 26.6 & 6.7 \\
\hline
\end{tabular}

Table 3 summarizes the measured response time of UCF-216, using a $\mathrm{d}=5.01 \mu \mathrm{m}$ test cell at $\lambda=633 \mathrm{~nm}$ and $\mathrm{T}=40^{\circ} \mathrm{C}$ and $50^{\circ} \mathrm{C}$. From Table $4, \mathrm{UCF}-216$ can achieve $10.06 \mathrm{~ms}$ at $\mathrm{T}=40^{\circ} \mathrm{C}$ with $V_{2 \pi}$ $=2.93 V_{r m s}$, and $6.48 \mathrm{~ms}$ at $50^{\circ} \mathrm{C}$ with $V_{2 \pi}=3.0 V_{r m s}$. It should be mentioned that our allowed $V_{2 \pi}$ is $5 V_{r m s}$. If we operate $\mathrm{UCF}-216$ at $50^{\circ} \mathrm{C}$, we can use a slightly thinner cell gap $(4.14 \mu \mathrm{m}$ in transmissive mode or $2.07 \mu \mathrm{m}$ in reflective $\operatorname{LCoS} @ 50{ }^{\circ} \mathrm{C}$ ) to increase $V_{2 \pi}$ to $5 V_{r m s}$. Under such condition, the rise time can be reduced. From Table 4 , the total response time $\tau_{\text {on }}+\tau_{\text {off }}=3.14 \mathrm{~ms}$, which enables LCoS SLM to be operated at $\sim 300 \mathrm{~Hz}$.

Table 4. Measured response time of a transmissive UCF-216 cell with $\mathrm{d}=5.01 \mu \mathrm{m}$, and the extrapolated response time to the corresponding reflective cells at $40^{\circ} \mathrm{C}$ and $50^{\circ} \mathrm{C} . \lambda=633 \mathrm{~nm}$.

\begin{tabular}{cccccccc}
\hline $\begin{array}{c}\mathbf{T} \\
\left({ }^{\circ} \mathbf{C}\right)\end{array}$ & $\begin{array}{c}\mathbf{d} \\
(\boldsymbol{\mu \mathbf { m }})\end{array}$ & $\boldsymbol{V}_{\boldsymbol{t h}}(\mathbf{V})$ & $\boldsymbol{V}_{\mathbf{2 \pi}}(\mathbf{V})$ & $\boldsymbol{\tau}_{\mathbf{o n}}(\mathbf{m s})$ & $\boldsymbol{\tau}_{\mathbf{o f f}}(\mathbf{m s})$ & $\begin{array}{c}\boldsymbol{\tau}_{\text {total }}(\mathbf{m s}) \\
\text { Transmissive }\end{array}$ & $\begin{array}{c}\boldsymbol{\tau}_{\text {total }}(\mathbf{m s}) \\
\text { Reflective }\end{array}$ \\
\hline 40 & 5.01 & 1.3 & 2.93 & 18.53 & 21.69 & 40.22 & 10.06 \\
40 & 4.00 & 1.3 & 5.0 & 3.49 & 13.83 & 17.32 & 4.33 \\
50 & 5.01 & 1.2 & 3.0 & 11.14 & 14.8 & 25.94 & 6.48 \\
50 & 4.14 & 1.2 & 5.0 & 2.44 & 10.1 & 12.54 & 3.14 \\
\hline
\end{tabular}

\subsection{Photostability}

To investigate the photostability of TL-216 and UCF-216, we prepared the test cells using indium tin oxide (ITO)-glass substrates overcoated with a thin inorganic $\mathrm{SiO}_{\mathrm{x}}$ alignment layer. In experiment, we injected TL-216 into a 9- $\mu$ m-thick homogeneous cell with $\mathrm{SiO}_{x}$ alignment layers. To perform an accelerated photostability test, we employed a high-power CW blue diode laser with $\lambda=465 \mathrm{~nm}$. The peak power was $9 \mathrm{~W}$, and the laser intensity was kept at $200 \mathrm{~W} / \mathrm{cm}^{2}$. We exposed the test cell for one day and then took it out from the exposure system for about $30 \mathrm{~min}$ to measure its birefringence (blue circles) and viscoelastic constant (red squares). After the measurements, we put the sample back to the irradiation system for further exposure. The measured results are recorded in Figure 6. As the dosage increased, $\Delta n$ and $\gamma_{1} / K_{11}$ remain basically unchanged. We also measured the photostability of UCF-216 and the results are as stable as TL-216 shown in Figure 6 because our fluorinated terphenyl compound has an excellent photostability at $\lambda=465 \mathrm{~nm}$. From Figure 6, both TL-216 and UCF-216 show no sign of degradation even though the total dosage exceeded $400 \mathrm{MJ} / \mathrm{cm}^{2}$. 


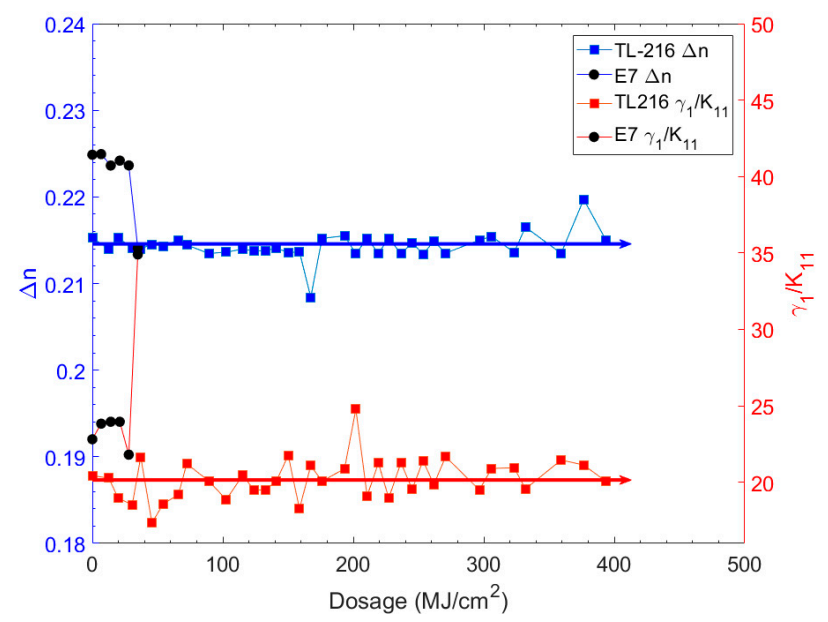

Figure 6. Measured photostability of E7 and Merck TL-216 with a blue laser at $\lambda=465 \mathrm{~nm}$ at $22{ }^{\circ} \mathrm{C}$. Probing laser $\lambda=633 \mathrm{~nm}$.

Based on Merck's publications [33,34] and judging from its birefringence, the major compositions of TL 216 are likely to be chlorinated and fluorinated terphenyls. These compounds offer a modest birefringence $(\Delta n \approx 0.21)$ and dielectric anisotropy $(\Delta \varepsilon \approx 5)$, and more importantly, excellent photostability in the blue wavelength.

Included in Figure 6 are the photostability data of E7, which consists of 92\% cyano-biphenyl (51\% 5CB, 25\% 7CB and 16\% 8OCB) and 8\% cyano-terphenyl (5CT) compounds. To our surprise, E7 was degraded after $30 \mathrm{MJ} / \mathrm{cm}^{2}$, which implies $5 \mathrm{CT}$ is not stable enough under blue light irradiation. From the polarized absorption spectra of 5CT [35], the longest $\pi \rightarrow \pi^{*}$ transition band occurs at $306 \mathrm{~nm}$ and the tail diminishes when $\lambda>400 \mathrm{~nm}$. We also measured the transmission spectrum of a $9 \mu \mathrm{m} \mathrm{E7}$ cell in the UV-visible region and did not find any noticeable absorption at $\lambda=465 \mathrm{~nm}$.

We inspected the damaged patterns of the E7 cell under a white light table between two crossed polarizers. Figure 7 shows the photo. The deteriorated part turns to black between crossed polarizers. This implies that the LC material changed from homogeneous alignment to vertical alignment after degradation. Next, we applied a voltage to the test cell and found the damaged area is no longer switchable, which further confirms its vertical alignment. Although the detailed degradation mechanism of E7 is still under investigation, these data shed important insight for tailoring fast-response LC phase modulators while keeping an excellent photostability.

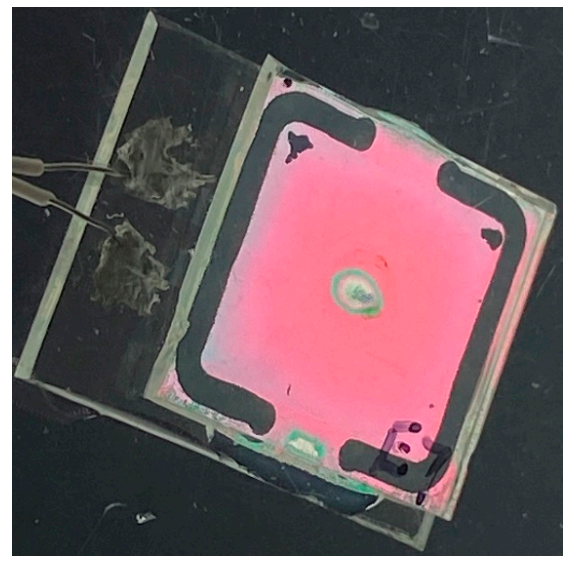

Figure 7. A photo of damaged E7 test cell taken between crossed polarizers on a white light table. The pink area shows homogeneous alignment, the middle circle is the laser exposure area, and the black spot is the damaged pattern. Both filling holes were sealed by epoxy sealants. 


\section{Conclusions}

In conclusion, we have developed a new LC mixture, designated as UCF-216, which is suitable for high brightness LCoS SLMs. The mixture exhibits fast response time $\left(\sim 3.14 \mathrm{~ms} @ 50^{\circ} \mathrm{C}\right)$, low operation voltage $(5 \mathrm{~V})$, and excellent photostability. Under a blue laser $(\lambda=465 \mathrm{~nm})$ illumination, UCF-216 shows no sign of degradation, even when the accumulated dosage exceeds $400 \mathrm{MJ} / \mathrm{cm}^{2}$. In comparison, E7 died at about $30 \mathrm{MJ} / \mathrm{cm}^{2}$ under the same exposure conditions. Practical applications of UCF-216 for laser-based SLMs, high brightness AR displays, and head-up displays are foreseeable.

Author Contributions: Methodology, Q.Y., J.Z. and Y.L.; writing—original draft preparation, Q.Y.; writing一review and editing, S.-T.W.; supervision, S.-T.W. All authors have read and agreed to the published version of the manuscript.

Funding: Sony Corporation.

Acknowledgments: The UCF group is indebted to Sony Corp. for the financial support, and Akiko Toriyama and Koichi Nagasawa for technical collaboration and useful discussion.

Conflicts of Interest: The authors declare no conflict of interest.

\section{References}

1. Schadt, M. Milestone in the History of Field-Effect Liquid Crystal Displays and Materials. Jpn. J. Appl. Phys. 2009, 48, 03B001. [CrossRef]

2. Huang, Y.; Hsiang, E.L.; Deng, M.Y.; Wu, S.T. Mini-LED, Micro-LED and OLED displays: Present status and future perspectives. Light Sci. Appl. 2020, 9, 105. [CrossRef]

3. Zhan, T.; Yin, K.; Xiong, J.; He, Z.; Wu, S.T. Augmented reality and virtual reality: Perspectives and challenges. iScience 2020, 23, 101397. [CrossRef]

4. Chen, H.; Lee, J.H.; Lin, B.Y.; Chen, S.; Wu, S.T. Liquid crystal display and organic light-emitting diode display: Present status and future perspectives. Light Sci. Appl. 2018, 7, 17168. [CrossRef]

5. Kirsch, P.; Bremer, M. Nematic Liquid Crystals for Active Matrix Displays: Molecular Design and Synthesis. Angew. Chem. 2000, 112, 4384-4405. [CrossRef]

6. Hird, M. Fluorinated liquid crystals-Properties and applications. Chem. Soc. Rev. 2007, 36, 2070-2095. [CrossRef]

7. Chen, H.; Hu, M.; Peng, P.; Li, J.; An, Z.; Wu, S.T. Ultra-low viscosity liquid crystals. Opt. Mater. Express 2015, 5, 655-660. [CrossRef]

8. Zhang, Z.; You, Z.; Chu, D. Fundamentals of phase-only liquid crystal on silicon (LCOS) devices. Light Sci. Appl. 2014, 3, e216. [CrossRef]

9. Cuypers, D.; de Smet, H.; van Calster, A. VAN LCOS microdisplays: A decade of technological evolution. J. Disp. Technol. 2011, 7, 127-134. [CrossRef]

10. Chen, H.M.; Yang, J.P.; Yen, H.T.; Hsu, Z.N.; Huang, Y.; Wu, S.T. Pursuing high quality phase-only liquid crystal on silicon (LCoS) devices. Appl. Sci. 2018, 8, 2323. [CrossRef]

11. Hu, L.; Xuan, L.; Liu, Y.; Cao, Z.; Li, D.; Mu, Q. Phase-only liquid-crystal spatial light modulator for wave-front correction with high precision. Opt. Express 2004, 12, 6403-6409. [CrossRef]

12. Bahk, S.W.; Fess, E.; Kruschwitz, B.E.; Zuegel, J.D. A high-resolution, adaptive beam-shaping system for high-power lasers. Opt. Express 2010, 18, 9151-9163. [CrossRef]

13. Crossland, W.A.; Wilkinson, T.D.; Manolis, I.G.; Redmond, M.M.; Davey, A.B. Telecommunications applications of LCOS devices. Mol. Cryst. Liq. Cryst. 2002, 375, 1-13. [CrossRef]

14. Lee, Y.H.; Tan, G.; Zhan, T.; Weng, Y.; Liu, G.; Gou, F.; Peng, F.; Tabiryan, N.V.; Gauza, S.; Wu, S.T. Recent progress in Pancharatnam-Berry phase optical elements and the applications for virtual/augmented realities. Opt. Data Process. Storage 2017, 3, 79-88. [CrossRef]

15. Zhan, T.; Xiong, J.; Zou, J.; Wu, S.T. Multifocal displays: Review and prospect. PhotoniX 2020, 1, 10. [CrossRef]

16. Hua, H. Enabling focus cues in head-mounted displays. Proc. IEEE 2017, 105, 805-824. [CrossRef]

17. Zhan, T.; Lee, Y.H.; Tan, G.; Xiong, J.; Yin, K.; Gou, F.; Zou, J.; Zhang, N.; Zhao, D.; Yang, J.; et al. Pancharatnam-Berry optical elements for head-up and near-eye displays. J. Opt. Soc. Am. B 2019, 36, D52-D65. [CrossRef] 
18. Maimone, A.; Georgiou, A.; Kollin, J.S. Holographic near-eye displays for virtual and augmented reality. ACM Trans. Graph. 2017, 36, 85. [CrossRef]

19. Matsuda, N.; Fix, A.; Lanman, D. Focal surface displays. ACM Trans. Graph. 2017, 36, 86. [CrossRef]

20. Huang, Y.; Liao, E.; Chen, R.; Wu, S.T. Liquid-Crystal-on-Silicon for augmented reality displays. Appl. Sci. 2018, 8, 2366. [CrossRef]

21. Fan-Chiang, K.H.; Huang, S.H.; Shen, C.Y.; Wang, H.L.; Li, Y.W.; Tsai, H.C.; Huang, Y.P. Analog LCOS SLM devices for AR display applications. J. Soc. Inf. Disp. 2020, 28, 581-590. [CrossRef]

22. Wu, S.T.; Lackner, A.M.; Efron, U. Optimal operation temperature of liquid crystal modulators. Appl. Opt. 1987, 26, 3441-3445. [CrossRef]

23. Lackner, A.M.; Margerum, J.D.; Miller, L.J.; Smith, W.H., Jr. Near ultraviolet photostability of liquid-crystal mixtures. Mol. Cryst. Liq. Cryst. 1986, 141, 289-310. [CrossRef]

24. Yakovenko, S.; Konovalov, V.; Brennesholtz, M. Lifetime of single panel LCOS imagers. SID Symp. Dig. Tech. Pap. 2004, 35, 64-67. [CrossRef]

25. Janning, J.L. Thin film surface orientation for liquid crystals. Appl. Phys. Lett. 1972, 21, 173-174. [CrossRef]

26. Wen, C.H.; Gauza, S.; Wu, S.T. Photostability of liquid crystals and alignment layers. J. Soc. Inf. Disp. 2005, 13, 805-811. [CrossRef]

27. Chen, Y.; Sun, J.; Xianyu, H.; Wu, S.T.; Liang, X.; Tang, H. High birefringence fluoro-terphenyls for thin-cell-gap TFT-LCDs. J. Display Technol. 2011, 7, 478-481. [CrossRef]

28. Wu, S.T.; Efron, U.; Hess, L.D. Birefringence measurements of liquid crystals. Appl. Opt. 1984, 23, $3911-3915$. [CrossRef]

29. Wu, S.T. Birefringence dispersions of liquid crystals. Phys. Rev. A 1986, 33, 1270-1274. [CrossRef]

30. Wu, S.T. Design of a liquid-crystal-based electro-optic filter. Appl. Opt. 1989, 28, 48-52. [CrossRef]

31. Huang, Y.; He, Z.; Wu, S.T. Fast-response liquid crystal phase modulators for augmented reality displays. Opt. Express 2017, 25, 32757-32766. [CrossRef]

32. Chen, H.; Gou, F.; Wu, S.T. Submillisecond-response nematic liquid crystals for augmented reality displays. Opt. Mater. Express 2017, 7, 195-201. [CrossRef]

33. Goulding, M.J.; Greenfield, S.; Coates, D.; Clemitson, R. Lateral fluoro substituted 4-alkyl-4"'-chloro-1, $1^{\prime}: 4^{\prime}, 1^{\prime \prime}$-terphenyls and derivatives. Useful high birefringence, high stability liquid crystals. Liq. Cryst. 1993, 14, 1397-1408. [CrossRef]

34. Pauluth, D.; Tarumi, K. Advanced liquid crystals for television. J. Mater. Chem. 2004, 14, $1219-1227$. [CrossRef]

35. Wu, S.T.; Ramos, E.; Finkenzeller, U. Polarized UV spectroscopy of conjugated liquid crystals. J. Appl. Phys. 1990, 68, 78-85. [CrossRef] 